\title{
HYGIENIC RECOMMENDATIONS FOR SAVING HEALTH OF CHILDREN IN THE QUARANTINE
}

\author{
Hozak S.V. https://orcid.org/0000-0002-6379-7331 \\ Stankevych T.V. https://orcid.org/0000-0003-3998-3748 \\ Yelizarova O.T. https://orcid.org/0000-0002-2860-9059 \\ Parats A.N. https://orcid.org/0000-0003-4301-5336
}

\author{
State Institution "O.M. Marzieiev Institute for Public Health of the National Academy \\ of Medical Sciences of Ukraine", Kyiv, Ukraine \\ school_health@meta.ua
}

\begin{abstract}
Relevance. The introduction of the quarantine measures in Ukraine during COVID-19 pandemic radically changed all aspects of children's lifestyle. Restricting of social contacts and travelling, introduction of distance education are typical manifestations of quarantine measures' application to schoolchildren. However, social distancing, the effects of the negative factors of distance education and prolonged stress can threaten the health of school-age children both at the moment and have delayed consequences. The assistance of the optimal adaptation process to new conditions decreases risks to children's health at various levels: physical, psychical, social

Objective. Development of hygienic recommendations for saving the health of schoolchildren during the quarantine.

Methods. Structural-logical and analytical methods were used, based on our own 20-year research and research by other authors, WHO and CDC recommendations. The results of our research before and during the quarantine have been presented.

Results. During the introduction of quarantine measures, the health of a schoolchild is formed under the influence of a complex of factors, among which a significant place is occupied by controlled ones: properly organized learning process, daily routine, including diet and drinking regime, ensuring sufficient physical activity and night rest. To ensure the optimal course of adaptation of children in conditions of social isolation, it is also necessary to take into account the individual characteristics of children, the peculiarities of the circadian rhythm of schoolchildren of different age groups, their physical and mental development.

Conclusions. Maintaining and strengthening the health of children in quarantine depends on the individual characteristics of development and health of the child, the optimal organization of distance learning, ensuring sufficient duration of physical activity, sleep, screen time, optimization of nutrition and water consumption schedule. The promotion of health maintenance and specific recommendations would help reduce the negative influence of the quarantine measures on the formation of children's health.
\end{abstract}

Keywords: hygienic recommendations, saving children's health, the quarantine, organizing lifestyle, distance education

Relevance. Social isolation, lockdown, quarantine - these words have confidently entered the lexicon, this is a new reality. The characteristic manifestations of the life of the population, including children, in the new conditions include the restriction of social contacts, restrictions on movement, distance learning. The optimal course of adaptation to new conditions reduces the risk of health problems in children at different levels: physical, mental, social [1].

During the spread of infectious disease in the population, the risk of damage to all segments of the population, including children and adolescents, therefore, as a preventive measure, school closure is considered as one of the influencing factors $[2,3]$.

Forced stay at home during quarantine restrictions, or observation, dramatically changes all aspects of school life. First of all, motor activity is significantly reduced. It is known that motor inactivity, the so-called «sedentary behavior», is a separate independent risk factor for children's health disorders $[4,5]$. Our research in previous years found that a sedentary lifestyle is characteristic of $75.6 \%$ of modern urban middle school students, even in normal conditions. On average, a modern urban middle school student spends about 11 hours a day sitting or ly- ing down (except for a night's sleep). Girls are 2.5 times more likely to lead a sedentary lifestyle than boys [6].

Our research has shown that the probability of developing diseases in children increases by $20 \%$ at low levels of physical activity. The probability of multiple pathology (more than three diseases) increases in children and adolescents almost 4 times with a low level of physical activity, and the probability of neurosis -2.5 times. Students who have a screen time of more than two hours a day are also at risk of deteriorating health. According to our data, $65.8 \%$ of such students. This increases the likelihood of a decrease in performance by $45 \%[4,7]$.

Living in new conditions requires special attention to the prevention of posture disorders in children $[8,9]$. Musculoskeletal disorders occur during periods of intensive growth and development of the body in conditions of high levels of static, sensory and information load, low level of general motor activity, unbalanced diet, lack of special exercises to strengthen corset muscles, inconsistency of physical activity with morpho-functional features and the degree of individual fitness of the child's body; inconsistencies in the child's workplace growth and other factors. We have established a link between 
the formation of posture disorders in schoolchildren and decreased vital capacity of the lungs, deterioration of the visual analyzer, central and autonomic nervous system, cardiovascular system, digestive system, decreased mental capacity [11-14].

Quarantine restrictive measures, or observation, involve the maximum restriction of direct «live» social contacts. Studies conducted by scientists before the COVID-19 pandemic show that in conditions of deprivation in children and young people there is an increase in anxiety, hyperactivity, aggression, as well as various types of addiction (from sweets, alcohol and others) [15]. The results of our own research showed that adaptation to new living conditions was easier and faster for people who were able to create and maintain a virtual circle of communication and received support from teachers [16].

Objective: Development of hygienic recommendations for saving the health of schoolchildren during the quarantine.

\section{MATERIALS AND METHODS}

When writing the recommendations, structural-logical and analytical methods were used, based on the use of our own 20-year research on the formation of the health of children and adolescents under the influence of vital factors, including during the COVID-19 pandemic. We also used research by other authors, materials from WHO, CDC.

\section{RESULTS AND DISCUSSION}

Most of the factors of schoolchildren's life, such as daily routine, living conditions, organization of education, organization and quality of food, and others, are controlled factors. That is, the impact on these determinants and the optimization of these aspects of life have a positive effect on the processes of maintaining and strengthening the health of children. A thorough study of certain factors and their impact on the formation of the health of school-age children during quarantine restrictive measures has allowed us to identify the main ones that need the most attention.

During the period of strict quarantine, the only possible form of schooling for students is distance learning. During this form of learning, communication between the subjects of distance learning during training and correctional and developmental classes, consultations is provided by the transmission of video, audio, graphic and textual information in synchronous or asynchronous mode. The procedure for organizing the educational process by distance learning is determined according to the orders of the Ministry of Education and Science of Ukraine «On approval of the Regulation on distance learning» from 25.04.2013 № 466 and «On approval of the Regulation on the institutional form of general secondary education» 23.04.2019 №536, as well as changes to these orders, which are reflected in the order «Some issues of distance learning» from 08.09.2020 № 1115 [17]. Also, when organizing the educational process, it is necessary to follow the Sanitary Regulations for general secondary education institutions, approved by the Order of the Ministry of Health of Ukraine dated 25.09.2020 № 2205 and registered in the Ministry of Justice of Ukraine on 10.11.2020 for № 1111/35394 [18].

The organization of the process of teaching a sckoolchild at home consists of the equipment of the workplace (educational furniture, digital devices, lighting), the duration and form of education, types of extracurricular activities, including physical activity.

The equipment of the place for the child must correspond to the anthropometric parameters of the sckoolchild [19]. You can determine the conformity of the desktop to the child's height visually. With the optimal posture of the child:

- $\quad 2 / 3$ of the length of the thigh are on the seat;

- the child's feet are on the floor or stand, the angle at the knee joint is straight;

- the front edge of the chair goes about $5 \mathrm{~cm}$ below the table surface, with the child's palm between the torso and the front edge of the table;

- the table surface is $2-6 \mathrm{~cm}$ above the elbow of the lowered arm of the sitting child.

If these conditions are met, the child's posture during training will be stable, the angle of the body is favorable, the shoulders are symmetrically located. This pose does not compress the internal organs and large vessels, while maintaining the required safe distance from the eyes to the table surface [19].

Given the growth process of the child during school, the most optimal are adjustable furniture. If it is not possible to buy a special adjustable desk, it is necessary to optimize the workplace: with a high chair on the floor you need to install a solid, stable footrest, and with a high table on the chair to put a hard pillow. To ensure that the child's eyes and body do not strain during reading, it is necessary to provide a perpendicular from the eyes to the book with a special book stand or tilt the table cover.

The format of using electronic devices during distance learning depends on the duration of quarantine and the age group of students. If the quarantine lasts no more than a week, it is acceptable to receive tasks through social networks and perform them yourself [20]. With a longer duration of quarantine, the introduction of interactive learning is necessary.

If a child of primary school age does not have a computer, the acquisition of new skills can cause an additional reaction to the stress that is observed due to unusual learning conditions. Therefore, in the first stage, you can use a regular tablet or smartphone when communicating with the teacher, as conference facilities such as Zoom, Discord, Skype, Hangouts, etc. do not require 
special equipment. Having a personal computer for a child of any age is especially important when the school uses e-learning systems (HUMAN, MOODLE or others). Each e-learning platform publishes the technical requirements of the means of communication, and these requirements must be taken into account when choosing an e-device. When using smartphones during distance learning, it is necessary to take into account such shortcomings in their work as small screen size, instability of Internet connection, high risk of disabling video conferencing during a phone call [21]. It is important to mark the place for distance learning of sckoolchildren in large families or small apartments physically, for example, with colored tape. A dedicated place for studing gives a feeling of control and security. At the same time during studing it is desirable to use earphones which have function of suppression of noise.

Emphasis should be placed on the following general conditions for the use of digital electronic devices during distance learning:

- the place of employment should be comfortable for the child and separated from the activities of other family members;

- the webcam should be at eye level;

- when using electronic devices outside the child should not lead to curvature of the spine and compression of internal organs;

- every 15-25 minutes of training it is necessary to take breaks for physical activity;

- $\quad$ electronic devices must meet the conditions of mental and physical development of the sckoolchild with a diagonal of video monitors (screens) not less than $35.56 \mathrm{~cm}$ (14 inches);

- during video conferences it is necessary to allocate time for communication of sckoolchildren among themselves.

For optimal functioning of musculoskeletal and visual analyzers and harmonious mental development of the child, it is necessary to provide a favorable light regime and color scheme in the room and workplace. The walls of light tones of yellow, pink, green colors have the most harmonious influence on the psychoemotional state of the child; furniture - the color of light natural wood. At the same time the materials creating a matte surface are used. For right-handed children, the light from the window and table lamp should fall on the left side, for left-handed children - on the right. Preference should be given to lamps that provide a sufficient level and uniformity of lighting throughout the work surface, the absence of flicker and acoustic noise [19].

Wet cleaning should be carried out regularly (preferably daily) and the apartment should be ventilated at least three times a day: in the morning, in the afternoon and half an hour before bedtime, including to reduce static electricity generated by e-learning tools [22].

Given the peculiarities of the biorhythmological ac- tivity of the organism at different ages, the educational process for better performance is desirable to begin in grades $1-4$ at 8: 30-9: 00; grades 5-9 - at 9: 30-10: 00; 10-11 - 10: 00-10: 30. According to the methodological recommendations of the Ministry of Education and Science of Ukraine, synchronous classes should start at 10 am and end at $1 \mathrm{pm}$ [23]. The duration of synchronous classes (audio, video conferencing or real-time chats) should be up to $30 \%$ of the total learning process. In other countries, training by video conferencing is recommended within 1-2 hours per day, which does not contradict domestic standards [24]. If children study according to the traditional classroom system, it is important not to exceed for 1 st grade students 20 lessons per week, 2nd $-21 ; 3$ rd $-22 ; 4$ th -23 ; 5th -27 ; 6th $-28 ; 7-9$ th -30 ; $10-11$ th $-32[4,25,26]$. Exceeding the number of school hours above these limits leads to an increase in the probability of a high level of severe fatigue in schoolchildren by 1.3-3.5 times.

To reduce the risk of visual analyzer depletion and severe fatigue, it is recommended to reduce the duration of lessons using electronic means to 25-30 minutes, as the duration of the screen time should not exceed 2 hours per day [27]. However, our research has shown that the duration of the educational process during quarantine in April-May 2020 with the use of electronic means has not changed [28].

For children of primary and secondary school age, the maximum duration of homework is recommended to be 1 hour per day, for students of senior school age -1.5 hours [4]. The probability of developing severe fatigue in children when these levels are exceeded is 2.2 times higher.

Active rest and physical activity. During distance learning, special attention should be paid to sufficient Physical activity (PA), as insufficient levels of PA are associated with the risk of cardiovascular disease, diabetes, diseases of the musculoskeletal system, injuries, mental disorders (depression, anxiety). To prevent mental fatigue and increase the body's resistance to disease during distance learning every 15-20 minutes of continuous sitting, it is necessary to take breaks to change the type of activity from inactive to active [10]. The so-called «small», but quite significant, forms of physical activity are important for children's health: morning gymnastics, sports breaks during study or leisure, free movement and change of posture during lessons or homework [29-31]. In particular, you can use the exercises that are given in the guidelines «Healthy student» [32]. In addition, if the child is healthy, not in self-isolation, it is recommended to walk 1.5-2 hours a day in the fresh air, or engage in other types of physical activity. According to WHO recommendations [33] and CDC [34], daily physical activity from moderate to high intensity with a total duration of at least 60 minutes/day is recommended for children and adolescents. Moderate or intense aerobic exercise (brisk walking, running, cycling, rollerblading, etc.) is recom- 
mended daily, and strength training to strengthen muscles and bones - at least 3 days a week (Table 1). To prevent injury and overtraining, children should slowly increase their level of physical activity and change their activities.

Physical activity is also associated with subjective indicators of health and well-being. Our research showed that adolescents who consider themselves happy are engaged in 1.5-2.0 times longer sports of moderate intensity than students who feel less happy $(p<0.05)$ [35]. Therefore, it is necessary to help children remain physically active both in everyday life and in such special periods as quarantine.

However, both children and parents are often unable to properly assess whether a child has enough PA. According to our data, only $17 \%$ of children and $22 \%$ of parents believe that children lack PA, although in fact $41 \%$ of such children.

Our research has shown that the daily duration of total physical activity of children and adolescents should be at least 4.5 hours a day, and for classes of medium and high intensity, such as running, brisk walking, dancing, moving games, cycling, rollerblading, general physical training, strength exercises and most sports - it is necessary to allocate 50-60 minutes a day for boys, 40-50 minutes for girls; or 1.5 hours of sports 4 times a week for boys and 3 times for girls [4, 28]. The average duration of general PA of children during quarantine in April-May 2020. was about 2.5 hours/day at a rate of 4.5-5.5 hours, regardless of age and sex of children, ie twice less. It is safe to predict that long-term quarantine will adversely affect children's health.

According to our data, during distance learning only $63.6 \pm 1.6 \%$ of respondents noted that in their educational institutions were organized physical education classes or provided recommendations for physical education $(\mathrm{PE})$ in one form or another. Moreover, for $28.0 \%$ of sckoolchildren, the organization of PE during quarantine was limited only by oral or written recommendations of a physical education teacher. However, there is a great interest of children in the project «Rukhanka», which during the quarantine was introduced as part of the «All-Ukrainian School Online». Thus, $59.2 \%$ of schoolchildren, regardless of place of residence $\left(\chi^{2}=1.7 ; p>0.8\right)$, performed physical exercises in this format. This indicates the interest of children in physical exercises in the form of videos, especially emotionally colored, which should be used to increase physical activity not only during quarantine, but also during the normal learning process at school [28].

It is advisable for parents to engage in physical activity with their children at least once a day. These can

Table 1

Types of exercise for children and adolescents, according to the recommendations Centers for Disease Control and Prevention

(https://www.cdc.gov/healthyyouth/index.htm)

\begin{tabular}{|c|c|c|}
\hline \multirow{2}{*}{ Type PA } & \multicolumn{2}{|c|}{ Age groups } \\
\hline & 6-11 years & $12-18$ years \\
\hline $\begin{array}{l}\text { Aerobic exercise } \\
\text { moderate type }\end{array}$ & $\begin{array}{l}\text { - Fast walking } \\
\text { - Cycling (mostly on flat surfaces at moderate } \\
\text { speeds) } \\
\text { - Active recreation, such as hiking, scootering } \\
\text { without a motor, swimming } \\
\text { - Play active games, such as baseball }\end{array}$ & $\begin{array}{l}\text { - Fast walking } \\
\text { - Cycling (mostly on flat surfaces) } \\
\text { - Active recreation, such as kayaking, hiking, swimming } \\
\text { - Housework and gardening } \\
\text { - Play active games, such as baseball }\end{array}$ \\
\hline $\begin{array}{l}\text { Aerobic exercise } \\
\text { intensive type }\end{array}$ & $\begin{array}{l}\text { - Running } \\
\text { - Fast cycling } \\
\text { - Active running-related games, such as football } \\
\text { - Jump rope } \\
\text { - Cross-country skiing } \\
\text { - Initial level of martial arts } \\
\text { - Sports such as football, basketball, swimming and } \\
\text { tennis } \\
\text { - Energetic dances }\end{array}$ & $\begin{array}{l}\text { - Running } \\
\text { - Fast cycling } \\
\text { - Active running-related games, such as football } \\
\text { - Jump rope } \\
\text { - Cross-country skiing } \\
\text { - Martial arts } \\
\text { - Sports such as football, basketball, swimming and } \\
\text { tennis } \\
\text { - Energetic dances }\end{array}$ \\
\hline $\begin{array}{l}\text { Exercises } \\
\text { for muscle } \\
\text { strengthening }\end{array}$ & $\begin{array}{l}\text { - Tug of war } \\
\text { - Resistance exercises using body weight or } \\
\text { resistance bands } \\
\text { - Climbing on a rope or wood } \\
\text { - Climbing the playground equipment } \\
\text { - Some forms of yoga }\end{array}$ & $\begin{array}{l}\text { - Tug of war } \\
\text { - Resistance exercises using body weights, resistance } \\
\text { bands and exercise machines } \\
\text { - Some forms of yoga }\end{array}$ \\
\hline $\begin{array}{l}\text { Exercises } \\
\text { for bone } \\
\text { strengthening }\end{array}$ & $\begin{array}{l}\text { - Running } \\
\text { - Sports that involve jumping or rapidly changing } \\
\text { direction }\end{array}$ & $\begin{array}{l}\text { - Jump rope } \\
\text { - Running } \\
\text { - Sports that involve jumping or rapidly changing } \\
\text { direction }\end{array}$ \\
\hline
\end{tabular}


be activities at home - dancing, stretching exercises, strength exercises, or outdoors - moving games, cycling or rollerblading. We found a positive effect of joint physical activity of parents and children on children's health: a higher level of health is inherent in children who, together with their parents, engage in physical activity as in the fresh air $\left(\chi^{2}=7.96 ; p<0.05\right)$, and at home $\left(\chi^{2}=6.47\right.$; $p<0.05)[4,37]$.

According to our survey (2017-2018), 66\% of parents indicated that at least once in the last 30 days engaged in physical activity with the child in the fresh air (joint games, hiking, etc.). Parents pay much less attention to joint PA at home - only $29 \%$ indicated that they had exercised with their child at home at least once in the last 7 days [4].

Our research has shown that the personal example of parents regarding PA classes also has a positive effect on children's PA. Children and adolescents are more likely to attend sports sections or dance clubs if at least one of them does sports at home or in a fitness center $(p<0.05$ $0.001)$. Similar results were also obtained in the works of other authors [38-40].

Food and drinking. During quarantine, an important aspect of the daily routine is nutrition and drinking. It is important to provide children with a complete diet, which includes vegetables, fruits, meat, fish and seafood, cereals, eggs, dairy products, as well as the optimal mode of multiplicity of meals [22]. The diet of children can be individual depending on living and learning conditions, health status, physical activity. It is desirable that the intervals between meals do not exceed 3-3.5 hours [41]. According to our data, the actual diet of modern children and adolescents is characterized by insufficient consumption of products such as fish and seafood in $60 \%$ of students, meat, butter, eggs and milk $-22 \%$, dairy products $-13 \%$, fruit $-9 \%$ of students $[41,42]$. At the same time, $45 \%$ of sckoolchildren consume «unhealthy» products every day: sweet carbonated drinks, mayonnaise and ketchup $-57 \%$, sausages $-74 \%$, chips and crackers $-21 \%$ of sckoolchildren [41]. During the period from 5 th to 9 th grade, the number of children with poor nutrition increases 2.5 times.

It has been found that sckoolchildren with optimal nutrition make fewer mistakes during mental work. With poor nutrition, the probability of severe fatigue in sckoolchildren is $30 \%$ higher than with satisfactory.

Water consumption should be balanced with its excretion from the body. Water deficiency is especially dangerous during the challenges that the body receives from the adverse effects of a polluted environment, intense physical activity and, especially, during illness [43]. Insufficient water consumption also reduces the cognitive functions of schoolchildren [44]. Total water consumption includes drinking water, water in beverages and water that is part of food [45]. The required amount of water per day depends on the age and sex of the child, as well as physical activity. The European Food Safety Authority recommends that children aged 4 to 8 drink about 1.0-1.1 L/day, girls aged 9-13 - 1.3-1.5 L/day, and boys 9-13 years $-1.5-1.7 \mathrm{~L} /$ day [46]. The drinking regime of adolescents over 14 years of age should correspond to the drinking regime of an adult - about $2.0 \mathrm{~L} /$ day for girls and about $2.5 \mathrm{~L} /$ day for boys.

A night's sleep. The question of the duration and quality of schoolchildren's night rest is relevant both during everyday life and during quarantine. Sleep deprivation is known to increase the risk of developing chronic diseases such as insulin resistance, obesity, deteriorating mental health, and injuries, weight and behavioral problems [47-53]. Indicators of mental capacity of sckoolchildren are also sensitive to the factor of «night sleep». The probability of high levels of sckoolchildren fatigue is $30 \%$ higher with sleep deprivation than with sufficient sleep duration. With a lack of sleep, the amount of mental work of students decreases by $7-11 \%$, and the number of errors increases by $20-22 \%[10,54]$. The sleep duration recommended by the American Academy of Sleep Medicine for optimal health of children aged 6-12 years is 9-12 hours / day, and for adolescents aged 13-18 years - 8-10 hours / day [55]. According to our research, the optimal duration of sleep to maintain mental performance and reduce the risk of neurosis for children 6-11 years should be at least 10 hours, for adolescents 12-15 years at least 9 hours, for adolescents 16-18 years - at least 8 hours per day, in accordance with international recommendations $[22,54]$.

Figure 2 presents the recommendations of The International Association for Child and Adolescent Psychiatry and Allied Professions 'to ensure healthy sleep in children [56].

To implement the mechanisms of healthy sleep, it is necessary for the child to fall asleep and wake up at the same time. It is necessary to eliminate such irritants in the bedroom as electrical appliances with a bright display. In the bedroom you need to create a favorable microclimate for sleep. The air temperature in the cold season should be in the range of $18-22^{\circ} \mathrm{C}$, and in the warm $-22-25^{\circ} \mathrm{C}$; humidity $40-60 \%$. But to apply these recommendations it is necessary taking into account comfort for the individual, after all the pleasant temperature mode is defined individually.

As a result of the introduction of distance education, in addition to adapting to an unusual method of teaching, students experience psychological discomfort due to loss or severe restriction of face-to-face communication with school friends and teachers, as well as cases of interruption due to poor technical capabilities. Obviously, the biggest problems arise in children who grow up in low-income families who do not have the necessary technical means to organize the learning and life of their children. Anxiety and confusion are common disorders during social isolation in all age groups [57]. Therefore, during the implementation of quarantine measures, it is 


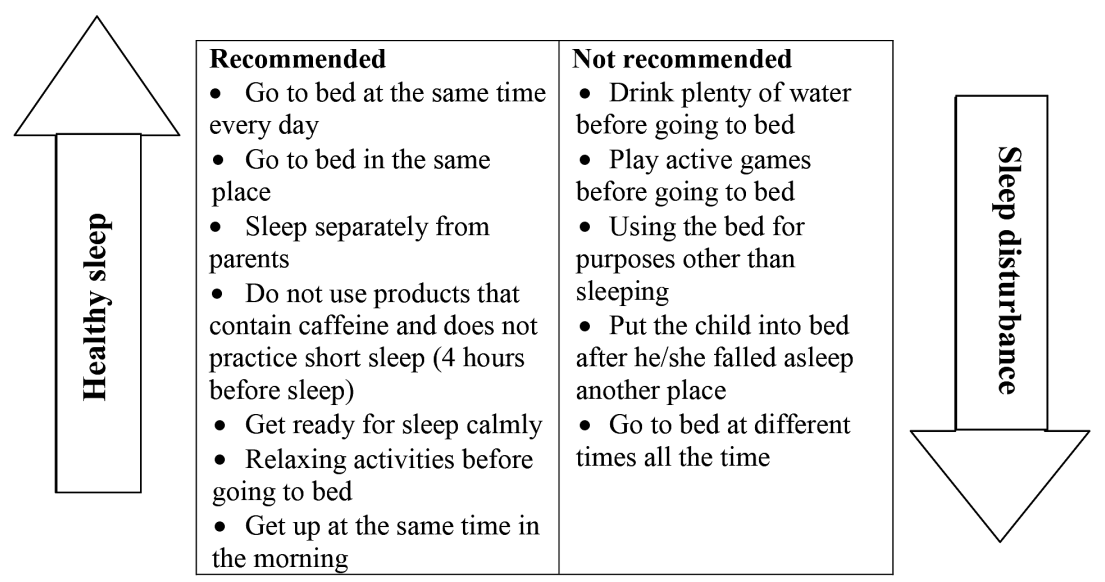

Fig. 2. Recommendations for sleep hygiene in children (The International Association for Child and Adolescent Psychiatry and Allied Professions')

necessary to take care of the physical and mental health of sckoolchildren, both on the part of parents and on the part of the educational institution.

Thus, the health of sckoolchildren during the implementation of quarantine measures is formed under the influence of a set of factors, among which a significant place is occupied by management: properly organized learning process, daily routine, including diet and drinking, adequate physical activity and night rest.

To ensure the optimal course of adaptation of children in conditions of social isolation, it is also necessary to take into account the individual characteristics of children, the peculiarities of the circadian rhythm of sckoolchildren of different ages, their physical and mental development.

\section{CONCLUSIONS}

Maintaining and strengthening the health of children in quarantine depends on the individual development and health of the child, the optimal organization of distance learning, ensuring sufficient duration of physical activity, sleep, limiting screen time, optimizing nutrition and drinking. Informing the public about the importance of these health components and specific recommendations will reduce the negative impact of social and physical isolation on children's health.

\section{REFERENCES}

1. World Health Organization. Mental health: strengthening our response. Geneva: World Health Organization, 2018.

View at: https://www.who.int/news-room/fact-sheets/ detail/mental-health-strengthening-our-response

2. Bramley A.M., Bresee J., Finelli L. Pediatric influenza. Pediatr Nurs. 2009; 35(6): 335-45. PMID: 20166462.

View at: PubMed: https://pubmed.ncbi.nlm.nih. gov/20166462/

3. Non-pharmaceutical public health measures for mitigating the risk and impact of epidemic and pandemic influenza. WHO Regional Office for Europe. Copenhagen. 2019. $131 \mathrm{p}$.

View at: URL: https://www.who.int/influenza/ publications/public health_measures/publication/en/ https://www.euro.who.int/__data/assets/pdf_ file/0019/424342/NPI_guide.pdf

https:/apps.who.int/iris/bitstream/handle/10665/329439/

WHO-WHE-IHM-GIP-2019.1-eng.pdf?ua=1

4. Hozak S. [Children's health in the conditions of modern challenges] [in Ukrainian].

View at: URL: http://amnu.gov.ua/ zdorov-ya-ditej-v-umovah-suchasnyh-vyklykiv/

5. Lee I.M., Shiroma E.J., Lobelo F., Puska P., Blair S.N., Katzmarzyk P.T. Effect of physical inactivity on major non-communicable diseases worldwide: an analysis of burden of disease and life expectancy. Lancet. 2012; 380(9838): 219-29. DOI: 10.1016/S0140-6736(12)61031-9. View at: Publisher Site: https://www.thelancet.com/ journals/lancet/article/PIIS0140-6736(12)61031-9/ fulltext

PubMed: https://pubmed.ncbi.nlm.nih.gov/22818936/ PubMed Central: https://www.ncbi.nlm.nih.gov/pmc/ articles/PMC3645500/

Europe PMC: https://europepmc.org/article/ $\mathrm{med} / 22818936$

6. Yelizarova O., Stankevych T., Parats A., Antomonov M., Polka N., Hozak S. Specific Features of the Ukrainian Urban Adolescents' Physical Activity: A Cross-Sectional Study. J Environ Public Health. 2020:3404285. DOI: $10.1155 / 2020 / 3404285$.

View at: Publisher Site: https://www.hindawi.com/ journals/jeph/2020/3404285/

PubMed: https://pubmed.ncbi.nlm.nih.gov/32351581/ PubMed Central: https://www.ncbi.nlm.nih.gov/pmc/ articles/PMC7171637/

7. Pol'ka N.S., Gozak S.V., Yelizarova O.T., Parats A.M., Stankevich T.V., Kalinichenko I.O., Zaïkina G.P., Latina G.O. [Mental efficiency, educational load and way of life of modern schoolchildren: hygienic aspects. Monograph]. Kyiv: MVC «Medinform», 2018. 214 p. [in Ukrainian]. 
View at: URL: http://www.irbis-nbuv.gov.ua/cgibin/irbis nbuv/cgiirbis 64.exe?Z21ID=\&I21DB$\mathrm{N}=\mathrm{EC} \& \mathrm{P} 21 \mathrm{DBN}=\mathrm{EC} \& \mathrm{~S} 21 \mathrm{STN}=1 \& \mathrm{~S} 21 \mathrm{REF}=10 \& \mathrm{~S}-$ $21 \mathrm{FMT}=$ fullwebr $\& \mathrm{C} 21 \mathrm{COM}=\mathrm{S} \& \mathrm{~S} 21 \mathrm{CNR}=20 \& \mathrm{~S}$ $21 \mathrm{P} 01=0 \& \mathrm{~S} 21 \mathrm{P} 02=0 \& \mathrm{~S} 21 \mathrm{P} 03=\mathrm{I}=\& \mathrm{~S} 21 \mathrm{COLORT}-$ ERMS $=1 \& S 21 \mathrm{STR}=\% \mathrm{D} 0 \% 92 \% \mathrm{D} 0 \% 90825945 \$$

8. Gaborets Yu.Yu., Dudina O.O. [Dynamics of morbidity of children in Ukraine in the regional aspect and the prevalence of diseases between them]. Ukraine. Nation's Health. 2017; 4: 18-28. [in Ukrainian]. View at: URL: http://nbuv.gov.ua/UJRN/Uzn_2017_4_5

9. Hozak S.V. [Influence of the organization of the educational process in schools on the formation of children's posture]. Hygiene of populated places. 2011; 58: 30510. [in Ukrainian].

10. Pol kka N.S., Gozak S.V., Stankevy`ch T.V., Yelizarova O.T., Paracz A.M. [Preventive program «Healthy schoolchildren to preserve and strengthen the health of secondary schools»: Guidelines]. Kyiv, 2018. 36 s [in Ukrainian].

View at: URL: http://www.health.gov.ua/www.nsf/16a436f1b0cca21ec22571b300253d46/9cc650f319694c45c22583c3004e45bd/\$FILE/_d0n60bk2vf9i6usivedhmgrrcc5p2qchg64s0_.pdf

11. Hozak S.V., Yelizarova O.T. [The morphofunctional state of schoolchildren and its dependence on the organization of physical education]. Medical Almanac. 2013; 6 (30): 156-9. [in Russian].

View at: URL: https://cyberleninka.ru/article/n/morfofunktsionalnoe-sostoyanie-shkolnikov-i-ego-zavisimost-ot-organizatsii-fizicheskogo-vospitaniya

12. Hozak S.V., Yelizarova O.T., Parats A., Filonenko O. [The influence of the factors of the organization of the educational process on the vegetative tonus of children of secondary school age]. Hygiene of populated places. 2014; 64: 265-71. [in Ukrainian].

View at: URL: http://irbis-nbuv.gov.ua/cgi-bin/irbis_nbuv/ cgiirbis_64.exe?C21COM=2\&I21DBN=UJRN\&P21DB$\mathrm{N}=\mathrm{UJRN} \& I M A G E \_F I L E \_D O W N L O A D=1 \&$ Image file name $=$ PDF $/ g n m \_2014 \_64$ 42.pdf

13. Afanasyev S. [Adaptation possibilities of the vegetative nervous system in primary school-aged children with positional disorders]. Theory and Methods of Physical Education and Sports. 2016; 2: 14-8. [in Ukrainian]. DOI: $10.32652 /$ tmfvs.2016.2.14-18.

View at: Publisher Site: http://tmfvs-journal.uni-sport. edu.ua/article/view/82952

14. Yelizarova O.T. [Hygienic assessment of out-of-school static workload of children aged 8-11 years]. Hygiene of populated places. 2015; 66: 258-62. [in Ukrainian]. View at: URL: http://nbuv.gov.ua/UJRN/ gnm 20156642.

15. Orben A., Tomova L., Blakemore S.J. The effects of social deprivation on adolescent development and mental health. The Lancet. Child Adolesc Health. 2020; 4(8): 634-40. DOI: 10.1016/S2352-4642(20)30186-3.

View at: Publisher Site: https:/www.thelancet.com/ journals/lanchi/article/PIIS2352-4642(20)30186-3/ fulltext
Scopus: https://covid19.elsevierpure.com/de/publications/the-effects-of-social-deprivation-on-adolescent-development-and-m

16. Hozak S., Yelizarova O., Stankevych T., Diuba N., Parats A., Lebedynets N. [Anxiety and depression of ukrainian school-age children in the process of distance education during the COVID-19 pandemic]. Bulletin of Taras Shevchenko National University of Kyiv. 2020; 1(11): 27-33. [in Ukrainian].

17. [On approval of the Regulation on distance learning]: Order of the Ministry of Education and Science of Ukraine 25.04.2013 № 466 [in Ukrainian].

View at: URL: https://zakon.rada.gov.ua/laws/show/ z0703-13\#Text

18. [Sanitary regulator for the institution of general secondary activity], approved by the Order of the Ministry of Health of Ukraine on 25.09.2020 № 2205 and registered in the Ministry of Justice of Ukraine on 10.11.2020. № 1111/35394 [in Ukrainian].

View at: URL: https://zakon.rada.gov.ua/laws/show/ z1111-20

19. Student workplace equipment. Recommendations of the laboratory of social development of children's health determinants of O.M. Marzieiev Institute of Public Health [in Ukrainian].

View at: URL: http://www.health.gov.ua/www.nsf/all/ u04-02-07-01-09

20. Sung Y.-T., Chang K.-E., Liu T.-C. The effects of integrating mobile devices with teaching and learning on students' learning performance: A meta-analysis and research synthesis. Computers \& Education. 2016; 94: 252-75. DOI: https://doi.org/10.1016/j. compedu.2015.11.008.

View at: Scopus: https://www.sciencedirect.com/ science/article/pii/S0360131515300804

21. Noah Darko-Adjei. The use and effect of smartphones in students' learning activities: evidence from the university of ghana, legon. Library Philosophy and Practice (e-journal). 2019; 2851.

View at: URL: https://digitalcommons.unl.edu/ libphilprac/2851

22. Hozak S. [The health of the child in quarantine. Recommendations for parents to maintain children's health and strengthen their immunity during the COVID-19 pandemic]. O.M. Marzieiev Institute of Public Health [in Ukrainian].

View at: URL: http://www.health.gov.ua/www.nsf/all/ u04-02-07-01?opendocument

23. Lototska A., Pasichnyk O. [Organization of distance learning in schools: methodical recommendations]. MES of Ukraine. 2020. 37 p. [in Ukrainian].

View at: URL: https://nus.org.ua/wp-content/uploads/2020/06/GRYF_Metodychni_rekomendatsii-_ dystantsiy-na_osvita_razvoroty.pdf

24. Reich J., Buttimer C.J., Fang A., Hillaire G., Hirsch K., Larke L.R., Littenberg-Tobias J., Slama R. Remote Learning Guidance From State Education Agencies During the COVID-19 Pandemic: A First Look. EdArX- 
iv, 2 Apr. 2020. Web. DOI: 10.35542/osf.io/437e2.

View at: Publisher Site: https://edarxiv.org/437e2

25. Hozak S., Yelizarova O., Parats A. [The regulation of school day load for school-age children]. Pedagogical sciences: theory, history, innovative technologies. 2017; 4 (68): 57-68. [in Ukrainian].

View at: URL: https://pedscience.sspu.sumy.ua/ wp-content/uploads/2018/04/417-\%D0\%B4\%D1\%80 $\%$ D $1 \% 83 \%$ D0\%BA.pdf

26. Yelizarova O.T., Hozak S.V., Parats A.M., Shumak O.V., Filonenko O.O. [Topicality of the optimization of day's routine and school day load in primary school-age children]. Environment\&Health. 2015; 4(75): 36-40. [in Ukrainian].

View at: URL: http://www.dovkil-zdorov.kiev. ua/Publ/dovkil.nsf/all/article?opendocument\&stype $=1 \mathrm{C} 3 \mathrm{D} 613835 \mathrm{BB} 84 \mathrm{EAC2257F3C00436DD3}$

27. Hozak S., Yelizarova O., Shumak O., Filonenko O. [Dependence of middleaged pupils mind activity on day organization]. Young Scientist. 2016 Sep; 9.1(36.1):504. [in Ukrainian].

View at: URL: http://molodyvcheny.in.ua/files/journal/2016/9/13.pdf

28. Hozak S., Yelizarova O., Parats A., Diuba N., Stankevych T. [Distance education characteristics of Ukrainian school children during the COVID-19 pandemic]. Bulletin of the Cherkasy Bohdan Khmelnytsky National University. Series «Pedagogical Sciences» 2020; 3:14-22. [in Ukrainian]. DOI: 10.31651/2524-2660-2020-3-14-22.

View at: URL: http://ped-ejournal.cdu.edu.ua/article/ download/3915/4180

29. Hozak S. [Examples of morning exercises and exercises that are potentially dangerous to the health of untrained children]. [in Ukrainian].

View at: URL: http://amnu.gov.ua/pryklady-fizychnyh-vprav-rankovoyi-gimnastyky-ta-vpravy-yaki-potenczijno-nebezpechni-dlya-zdorov-ya-netrenovanyh-ditej/

30. Recess Planning in Schools: A Guide to Putting Strategies for Recess into Practice. Atlanta, GA: Centers for Disease Control and Prevention, US Dept of Health and Human Services. 2017.

View at: URL: https://www.cdc.gov/healthyschools/ physicalactivity/pdf/2016_12_16_schoolrecessplanning_508.pdf

31. Increasing Physical Education and Physical Activity: A Framework for Schools. Atlanta, GA: Centers for Disease Control and Prevention, US Dept of Health and Human Services. 2017.

View at: URL: https://www.cdc.gov/healthyschools/ physicalactivity/pdf/17_278143-A_PE-PA-Framework_508.pdf

32. Polka N.S., Hozak S.V., Stankevych T.V. [Preventive program "Healthy schoolboy" to preserve and strengthen the health of students in secondary schools: guidelines]. Kyiv, 2018. 33 p. [in Ukrainian].

View at: URL: http://www.health.gov.ua/www.ns- f/16a436f1b0cca2 1 ec22571b300253d46/9cc650f319694c45c22583c3004e45bd/\$FILE/_d0n60bk2vf9i6usivedhmgrrcc5p2qchg64s0_.pdf

33. Bull F.C., Al-Ansari S.S., Biddle S., et al. World Health Organization 2020 guidelines on physical activity and sedentary behaviour. British Journal of Sports Medicine. 2020; 54: 1451-62. DOI: 10.1136/ bjsports-2020-102955.

View at: Publisher Site: https://bjsm.bmj.com/ content/54/24/1451

PubMed: https://pubmed.ncbi.nlm.nih.gov/33239350/ PubMed Central: https://www.ncbi.nlm.nih.gov/pmc/ articles/PMC7719906/

34. Physical Activity Guidelines for Americans, 2nd edition. Washington, DC: U.S. Department of Health and Human Services. 2018. 118 p.

View at: URL: https://health.gov/sites/default/ files/2019-09/Physical_Activity_Guidelines_2nd_edition.pdf

35. Hozak S. [Physical activity of children in conditions of social isolation]. Information laboratory of social factors that determine the health of children. O.M. Marzieiev Institute of Public Health [in Ukrainian]. View at: URL : http://www.health.gov.ua/www.nsf/all/ u05-02-83?opendocument

36. Hozak S.V., Yelizarova O.T., Antomonov M.Iu., Stankevych T.V., Parats A.M. [Hygienic recommendations for the optimal level of physical activity of middle school children]. Kyiv, 2019. 2 s. (Information sheet on innovation in healthcare of State Institution "Marzieiev Institute for Public Health of the National Academy of Medical Sciences of Ukraine № 2662019). [in Ukrainian].

View at: URL: http://www.health.gov.ua/www.nsf/16a436f1b0cca21ec22571b300253d46/9dbd04457d3 1d181c22583af0040cc79/\$FILE/Inf_lysr_266-2019.pdf

37. Hozak S.V., Stankevych T.V., Yelizarova O.T., Parats A.M., Dereviahina A.V. [Relationship between motor activity of adolescents and their parents]. Current public health issues: Mater. X All-Ukrainian of scientific-practical conference with international participation "Education and Health" (7-8 April 2020, Sumy). Sumy, 2020. Vol. 1 (4): 28-30. [in Ukrainian].

38. Anderssen N., Wold B. Parental and peer influences on leisure-time physical activity in young adolescents. Res Q Exerc Sport. 1992; 63(4): 341-8. DOI: 10.1080/02701367.1992.10608754.

View at: Publisher Site: https://www.tandfonline.com/ doi/abs/10.1080/02701367.1992.10608754

Europe PMC: https://europepmc.org/article/ med/1439157

39. Forthofer M., Dowda M., McIver K., Barr-Anderson D.J., Pate R. Associations Between Maternal Support and Physical Activity Among 5th Grade Students. Matern Child Health J. 2016; 20(3): 720-9. DOI: 10.1007/ s10995-015-1873-0.

View at: Scopus: https://link.springer.com/ article/10.1007/s10995-015-1873-0 
PubMed: https://pubmed.ncbi.nlm.nih.gov/26649880/

PubMed Central: https://www.ncbi.nlm.nih.gov/pmc/ articles/PMC4754126/

Europe PMC: https://europepmc.org/article/ $\mathrm{med} / 26649880$

40. Van Der Horst K., Paw M.J., Twisk J.W., Van Mechelen W. A brief review on correlates of physical activity and sedentariness in youth. Med Sci Sports Exerc. 2007; 39(8): 1241-50. DOI: 10.1249/mss.0b013e318059bf35. View at: Publisher Site: https://journals.lww.com/acsmmsse/Fulltext/2007/08000/A_Brief_Review_on_Correlates_of_Physical_Activity.6.aspx

PubMed: https://pubmed.ncbi.nlm.nih.gov/17762356/

41. [Recommendations for school nutrition]. Information of laboratory of social factors that determine the health of children. O.M. Marzieiev Institute of Public Health [in Ukrainian].

View at: URL: http://www.health.gov.ua/www.nsf/all/ u04-02-07-01-02

42. Hozak S., Yelizarova O., Stankevytch T., Parats A. [Factual nutrition of modern schoolchildren and its impact on mental efficiency and fatigue]. Environment \& Health. 2017; 3(83): 29-33. [in Ukrainian]. DOI: 10.32402/dovkil2017.03.029

View at: Publisher Site: http://www.dovkil-zdorov. kiev.ua/publ/dovkil.nsf/all/article_e?opendocument\&stype $=413212$ CE07CCBC24C22581B0003079B2

43. Recommendations for water use for children of different ages. Information of laboratory of social factors that determine the health of children. O.M. Marzieiev Institute of Public Health [in Ukrainian].

View at: URL: http://www.health.gov.ua/www.nsf/all/ u04-02-07-01-02

44. Kempton M.J., Ettinger U., Foster R., Williams S.C., Calvert G.A., Hampshire A. Zelaya F.O., McMorris T., Owen A.M., Smith M.S. Dehydration affects brain structure and function in healthy adolescents. Hum Brain Mapp. 2011; 32(1): 71-9. DOI: 10.1002/hbm.20999. View at: Publisher Site: https://onlinelibrary.wiley.com/ doi/full/10.1002/hbm.20999

PubMed: https://pubmed.ncbi.nlm.nih.gov/20336685/ PubMed Central: https://www.ncbi.nlm.nih.gov/pmc/ articles/PMC6869970/

45. Dietary reference intakes for water, potassium, sodium, chloride, and sulfate Institute of Medicine (US) Panel on Dietary Reference Intakes for Electrolytes and Water. Washington, D.C.: National Academies Press, 2005. 638 p. DOI: $10.17226 / 10925$

View at: URL: https://www.nap.edu/catalog/10925/ dietary-reference-intakes-for-water-potassium-sodium-chloride-and-sulfate

46. Scientific Opinion on Dietary Reference Values for water. EFSA Journal. 2010; 8(3): 1459. DOI: 10.2903/j. efsa.2010.1459

View at: Publisher Site: https://www.efsa.europa.eu/en/ efsajournal/pub/1459

URL: https://efsa.onlinelibrary.wiley.com/doi/pdf/10.2903/j.efsa. 2010.1459
47. Wheaton A.G., Chapman D.P., Croft J.B. School Start Times, Sleep, Behavioral, Health, and Academic Outcomes: A Review of the Literature. J Sch Health. 2016; 86(5): 363-81. DOI: 10.1111/josh.12388.

View at: Publisher Site: https://onlinelibrary.wiley.com/ doi/abs/10.1111/josh. 12388

PubMed: https://pubmed.ncbi.nlm.nih.gov/27040474/ PubMed Central: https:/www.ncbi.nlm.nih.gov/pmc/ articles/PMC4824552/

48. Cao M., Zhu Y., He B., Yang W., Chen Y., Ma J., Jing J. Association between sleep duration and obesity is ageand gender-dependent in Chinese urban children aged 6-18 years: a cross-sectional study. BMC Public Health. 2015; 15: 1029. DOI: 10.1186/s12889-015-2359-0.

View at: Publisher Site: https://bmcpublichealth.biomedcentral.com/articles/10.1186/ s12889-015-2359-0

PubMed: https://pubmed.ncbi.nlm.nih.gov/26446623/ PubMed Central: https://www.ncbi.nlm.nih.gov/pmc/ articles/PMC4596376/

49. Wang J., Adab P., Liu W., Chen Y., Li B., Lin R., Liu W., Cheng K.K., Pallan M. Prevalence of adiposity and its association with sleep duration, quality, and timing among 9-12-year-old children in Guangzhou, China. J Epidemiol. 2017; 27(11): 531-7. DOI: 10.1016/j.je.2016.11.003.

View at: Scopus: https:/www.sciencedirect.com/ science/article/pii/S0917504017301193?via\%3Dihub PubMed: https://pubmed.ncbi.nlm.nih.gov/28623055/ PubMed Central: https://www.ncbi.nlm.nih.gov/pmc/ articles/PMC5608611/

50. Dutil C., Chaput J.P. Inadequate sleep as a contributor to type 2 diabetes in children and adolescents. Nutr Diabetes. 2017; 7(5): 266. DOI: 10.1038/nutd.2017.19. View at: Publisher Site: https://www.nature.com/ articles/nutd201719

PubMed: https://pubmed.ncbi.nlm.nih.gov/28481337/ PubMed Central: https:/www.ncbi.nlm.nih.gov/pmc/ articles/PMC5518801/

51. Willis T.A., Gregory A.M. Anxiety Disorders and Sleep in Children and Adolescents. Sleep Med Clin. 2015; 10(2): 125-31. DOI: 10.1016/j.jsmc.2015.02.002

View at: Publisher Site: https://www.sleep.theclinics. com/article/S1556-407X(15)00014-4/fulltext

PubMed: https://pubmed.ncbi.nlm.nih.gov/26055860/

52. Alfano C.A., Zakem A.H., Costa N.M., Taylor L.K., Weems C.F. Sleep problems and their relation to cognitive factors, anxiety, and depressive symptoms in children and adolescents. Depress Anxiety. 2009; 26(6): 503-12. DOI: 10.1002/da.20443.

View at: Publisher Site: https://onlinelibrary.wiley.com/ doi/abs/10.1002/da.20443

PubMed: https://pubmed.ncbi.nlm.nih.gov/19067319/ Europe PMC: https://europepmc.org/article/ $\mathrm{med} / 19067319$

53. Matricciani L., Paquet C., Galland B., Short M., Olds T. Children's sleep and health: A meta-review. Sleep Med Rev. 2019; 46: 136-50. DOI: 10.1016/j.smrv.2019.04.011 View at: Scopus: https://www.sciencedirect.com/science/ 
article/abs/pii/S1087079219300188?via\%3Dihub PubMed: https://pubmed.ncbi.nlm.nih.gov/31121414/ Europe PMC: https://europepmc.org/article/ $\mathrm{med} / 31121414$

54. Hozak S., Yelizarova O., Stankevytch T., Parats A. [Night sleep duration in the pupils as a hygienic problem]. Environment\&Health. 2018; 1(85):68-72. [in Ukrainian]. DOI: 10.32402/dovkil2018.01.068.

View at: Publisher Site: http://www.dovkil-zdorov. kiev.ua/publ/dovkil.nsf/all/article_e?opendocument\&stype=90E6FED8F45C2204C225826B002A84C6

55. Paruthi S., Brooks L.J., D’Ambrosio C., Hall W.A., Kotagal S., Lloyd R.M., Malow B.A., Maski K., Nichols C., Quan S.F., Rosen C.L., Troester M.M., Wise M.S. Consensus statement of the American Academy of Sleep Medicine on the recommended amount of sleep for healthy children: methodology and discussion. J Clin Sleep Med. 2016; 12: 1549-61. DOI: 10.5664/jcsm.6288 View at: Publisher Site: https://jcsm.aasm.org/ doi/10.5664/jcsm.6288

PubMed: https://pubmed.ncbi.nlm.nih.gov/27707447/

PubMed Central: https://www.ncbi.nlm.nih.gov/pmc/ articles/PMC5078711/
56. JM REY'S IACAPAP. e-Textbook of Child and Adolescent Mental Health. IACAPAP. 2018. Vol. 1. 770 p. [in Russian].

View at: URL: https://iacapap.org/english

57. Loades M.E., Chatburn E., Higson-Sweeney N., Reynolds S., Shafran R., Brigden A., Linney C., McManus M.N., Borwick C., Crawley E. Rapid Systematic Review: The Impact of Social Isolation and Loneliness on the Mental Health of Children and Adolescents in the Context of COVID-19. J Am Acad Child Adolesc Psychiatry. 2020; 59(11): 1218-39. DOI: 10.1016/j. jaac.2020.05.009

View at: Publisher Site: https://jaacap.org/article/ S0890-8567(20)30337-3/fulltext

PubMed: https://pubmed.ncbi.nlm.nih.gov/32504808/ PubMed Central: https://www.ncbi.nlm.nih.gov/pmc/ articles/PMC7267797/

Scopus: https://www.sciencedirect.com/science/article/ abs/pii/S0890856720303373

\title{
ГІГІЄНІЧНІ РЕКОМЕНДАЦІЇ ЩОДО ЗБЕРЕЖЕННЯ ЗДОРОВ'Я ДІТЕЙ В УМОВАХ КАРАНТИНУ
}

\author{
Гозак С.В., Станкевич Т.В., Слізарова О.Т., Парац А.М.
}

\author{
ДУ «Інститут громадського здоров’я ім. О.М. Марзєєва НАМН України», Київ, Украӥна
}

school_health@meta.ua

Актуальність. Введення карантинних та обмежувальних заходів в Україні під час пандемії COVID-19 кардинально змінило всі аспекти життєдіяльності школярів. До характерних проявів життєдіяльності дітей у нових умовах можна віднести обмеження соціальних контактів, обмеження переміщення та дистанційне навчання. Але соціальна ізоляція, вплив негативних факторів дистанційної освіти та тривалий стрес можуть загрожувати здоров'ю дітей шкільного віку як на даний момент, так і мати відстрочені наслідки. Забезпечення оптимального перебігу процесів адаптації до нових умов знижує ризик порушення здоров’я дітей на різних рівнях: фізичному, психічному, соціальному.

Мета: розробити рекомендації щодо організації життєдіяльності школярів, що є надзвичайно важливим для збереження їх здоров'я в умовах викликів сьогодення.

Методи. При написанні рекомендацій був застосований структурно-логічний та аналітичний методи на основі використання власних 20-річних досліджень щодо формування здоров'я дітей та підлітків під впливом факторів життєдіяльності, в тому числі під час пандемії COVID-19, а також наукових досліджень інших авторів, матеріалів BOO3, CDC. Представлені результати наших досліджень як до, так і під час карантину.

Результати. Здоров'я школяра під час впровадження карантинних заходів формується під впливом комплексу факторів, серед яких значне місце займають керовані: правильно організовані процес навчання, розпорядок дня, в тому числі режим харчування та питний режим, забезпечення достатньої рухової активності та нічного відпочинку. Для забезпечення оптимального перебігу адаптації дітей в умовах соціальної ізоляції необхідно також враховувати індивідуальні особливості дітей, особливості циркадного ритму школярів різних вікових груп, їх фізичний та психічний розвиток.

Висновки. Збереження і зміцнення здоров'я дітей в умовах карантину залежить від індивідуальних особливостей розвитку і стану здоров'я дитини, оптимальної організації дистанційного навчання, забезпечення достатньої тривалості рухової активності, сну, обмеження екранного часу, оптимізації харчування і питного режиму. Інформування населення щодо важливості цих здоров'язберігаючих складових та конкретні рекомендації дозволять зменшити негативний вплив соціальної і фізичної ізоляції на здоров'я дітей.

Ключові слова: гігієнічні рекомендації, збереження здоров’я дітей, карантин, організація життєдіяльності школярів, дистанційна освіта 


\title{
ГИГИЕНИЧЕСКИЕ РЕКОМЕНДАЦИИ СОХРАНЕНИЯ ЗДОРОВЬЯ ДЕТЕЙ В УСЛОВИЯХ КАРАНТИНА
}

\section{Гозак С.В., Станкевич Т.В., Елизарова Е.Т., Парац А.Н.}

\author{
ГУ «Институт общественного здоровья им. А.Н. Марзеева НАМН Украины», Киев, Украина
}

school_health@meta.ua

Актуальность. Введение карантинных и ограничительных мер в Украине во время пандемии COVID-19 кардинально изменило все аспекты жизнедеятельности школьников. К характерным проявлениям жизнедеятельности детей в новых условиях можно отнести ограничение социальных контактов, ограничение перемещения и дистанционное обучение. Но социальная изоляция, влияние негативных факторов дистанционного образования и длительный стресс могут угрожать здоровью детей школьного возраста как на данный момент, так и иметь отсроченные последствия. Обеспечение оптимального течения процессов адаптации к новым условиям снижает риск нарушения здоровья детей на разных уровнях: физическом, психическом, социальном.

Цель: разработать рекомендации по организации жизнедеятельности школьников, что является чрезвычайно важным для сохранения их здоровья в условиях вызовов сегодняшнего дня.

Методы. При написании рекомендаций был применен структурно-логический и аналитический методы на основе использования собственных 20-летних исследований по формированию здоровья детей и подростков под влиянием факторов жизнедеятельности, в том числе во время пандемии COVID-19, а также научных исследований других авторов, материалов BO3, CDC. Представлены результаты наших исследований как до, так и во время карантина.

Результаты. Здоровье школьника при внедрении карантинных мероприятий формируется под влиянием комплекса факторов, среди которых значительное место занимают управляемые: правильно организованные процесс обучения, распорядок дня, в том числе режим питания и питьевой режим, обеспеченея достаточной двигательной активности и ночного отдыха. Для обеспечения оптимального течения адаптации детей в условиях социальной изоляции необходимо также учитывать индивидуальные особенности детей, особенности циркадного ритма школьников разных возрастных групп, их физическое и психическое развитие.

Выводы. Сохранение и укрепление здоровья детей в условиях карантина зависит от индивидуальных особенностей развития и состояния здоровья ребенка, оптимальной организации дистанционного обучения, обеспечения достаточной продолжительности двигательной активности, сна, ограничения экранного времени, оптимизации питания и питьевого режима. Информирование населения о важности этих здоровьесберегающих составляющих и конкретные рекомендации позволят уменьшить негативное влияние социальной и физической изоляции на здоровье детей.

Ключевые слова: гигиенические рекомендации, сохранение здоровья детей, карантин, организация жизнедеятельности школьников, дистанционное образование 